November 2019

\title{
Do Professions Represent Competence for Entry-to-Practice in Similar Ways? An Exploration of Competence Frameworks through Document Analysis
}

Jessica V. Rich

Queen's University, Kingston, jessica.rich@queensu.ca

Follow this and additional works at: https://digitalcommons.georgiasouthern.edu/ij-sotl

\section{Recommended Citation}

Rich, Jessica V. (2019) "Do Professions Represent Competence for Entry-to-Practice in Similar Ways? An Exploration of Competence Frameworks through Document Analysis," International Journal for the Scholarship of Teaching and Learning: Vol. 13: No. 3, Article 5.

Available at: https://doi.org/10.20429/ijsotl.2019.130305 


\title{
Do Professions Represent Competence for Entry-to-Practice in Similar Ways? An Exploration of Competence Frameworks through Document Analysis
}

\begin{abstract}
Professional accrediting and regulating bodies are increasingly trying to delineate the knowledge and skills needed for entry-to-practice for quality assurance and international labor mobility. The purpose of this study was to com-pare how professions describe and represent competence. Current, publicly accessible Canadian entry-to-practice competence frameworks for ten professions (Medicine, Nursing, Occupational Therapy, Pharmacy, Psychology, Social Work, Teaching, Engineering, Law, and Planning) were analyzed through content and inductive thematic analysis. Findings revealed that although professions describe similar core competencies across technical and intrinsic domains, systematic differences exist in the architectures of the frameworks. Professions with 'meta-competencies' describe competence as being more integrated/holistic. Whereas professions without meta-competencies describe competence as either behavioral-/performance-like lists of 'attributes' or groups of knowledge, skills, and ethical/professional values. How competence is represented within frameworks has implications for how professional education programs conceptualize competence and subsequently design and enact curricula, teaching and learning opportunities, and systems of assessment.
\end{abstract}

\section{Keywords}

competence, competency-based education, competence frameworks, professional education, entry-topractice, document analysis

\section{Creative Commons License}

(c) (i) $\ominus$

This work is licensed under a Creative Commons Attribution-Noncommercial-No Derivative Works 4.0 License.

\section{Cover Page Footnote}

The author would like to acknowledge Dr. Don Klinger, Dr. Sue Fostaty Young, and Dr. Catherine Donnelly for their insights in contributing to the revisions of this manuscript. 


\title{
Do Professions Represent Competence for Entry-to-Practice in Similar Ways? An Exploration of Competence Frameworks through Document Analysis
}

\author{
Jessica V. Rich \\ Queen's University, Kingston \\ Received 20 January 2019;Accepted 23 October 2019
}

\begin{abstract}
Professional accrediting and regulating bodies are increasingly trying to delineate the knowledge and skills needed for entry-to-practice for quality assurance and international labor mobility. The purpose of this study was to compare how professions describe and represent competence. Current, publicly accessible Canadian entry-to-practice competence frameworks for ten professions (Medicine, Nursing, Occupational Therapy, Pharmacy, Psychology, Social Work, Teaching, Engineering, Law, and Planning) were analyzed through content and inductive thematic analysis. Findings revealed that although professions describe similar core competencies across technical and intrinsic domains, systematic differences exist in the architectures of the frameworks. Professions with 'meta-competencies' describe competence as being more integrated/holistic. Whereas professions without meta-competencies describe competence as either behavioral-/performance-like lists of 'attributes' or groups of knowledge, skills, and ethical/professional values. How competence is represented within frameworks has implications for how professional education programs conceptualize competence and subsequently design and enact curricula, teaching and learning opportunities, and systems of assessment.
\end{abstract}

\section{INTRODUCTION}

When we go to see a professional for a service, what are we looking for? In most cases, we are seeking specialized care that we cannot provide ourselves or trust just about anybody to provide. And in going to see a professional, we assume that they know what they are doing and have our best interests at heart. We implicitly expect professionals to be competent in the services they provide to society. But is it naive for society to assume that professionals are competent?

In theory, professionals are distinguished from non-professionals by the ability to provide an essential social function; the achievement of a certain standard of specialized knowledge and skills, which can be used to address complex problems; a commitment to professional ethics, developed through a period of professional socialization; freedom of judgment to make professional decisions and recommendations in practice; and high prestige and financial compensation (Hoyle \& John, 1995). Even though professions can be distinguished by scope of practice and pathway(s) to licensure, a common requirement unifying professional practice is the successful completion of a professional education program at a higher/tertiary education institution.

Within professional education, there has been increasing international recognition of the importance of educational outcomes specifying the capacities and abilities we can expect from graduates who are ready to begin professional practice (Shaw, Cassel, Black \& Levinson, 2009). These outcomes have been broadly referred to as "competencies" and include the knowledge, skills, and attitudes needed for licensure and registration within a given profession and practice jurisdiction. Entry-level competencies are thought to serve multiple purposes: (I) Public protection, through explicit description of the requirements for registration and licensure to practice; (2) Professional protection, through a more explicit awareness of the expectations for safe and effective practice throughout a professional's career; (3) Professional mobility, through assisting regulators in clarifying and harmonizing standards of professional practice across provincial and international borders; and (4) Educational accountability, through the deliv- ery of government-funded professional education that prepares graduates to successfully achieve professional practice standards upon entry-to-practice (Tuxworth, 1989). As professional accrediting and regulating bodies adopt, adapt, and develop their entryto-practice competence frameworks, higher/tertiary education programs are expected to transform their educational programs to become increasingly competency-based.

Competency-based approaches to education differ from traditional higher education program models concerning structure, pedagogy, assessment and evaluation, faculty role and student interaction (Carraccio, Wolfsthal, Englander, Ferentz \& Martin, 2002; Pichette \&Watkins, 20I8). In traditional structure-/ process-based programs, instructors often lead students through an established curriculum over a pre-determined period of time and provide opportunities for feedback on structured learning experiences (e.g., labs, discussions, assignments, etc.). Periodically, students undergo evaluation (i.e., tests and exams) to determine and report on the acquisition of specific knowledge and skills. In competency-based programs, faculty have an important role to play in co-regulating learners' development of competence. They do this over variable periods of time, through ongoing formative assessment of performance, which is directly observed within authentic practice contexts (i.e., work-integrated learning opportunities, simulation, case studies, etc.) (Competency-Based Education Network, 2017; Rich, 2017). For many faculty, ongoing formative assessment-involving dialogic feedback and competency-focused instruction-represents a significant paradigm shift in their approach to teaching and learning. Faculty development has been identified as an important, yet often "missing link" in operationalizing competency-based education (Holmboe et al., 20I I).

To guide pedagogical decision-making and scholarship within competency-based programs, it is important for faculty to have a foundational understanding of competence as a construct. However, in looking at the published literature for guidance, readers may be confused by longstanding tensions within competence as a concept. These tensions are worth reviewing, briefly, before explicitly stating the problem to be investigated in this research. 


\section{Conceptions of Competence}

In the 1980s and 90s, amid the downturn of the Competency-Based Teacher Education (CBTE) movement in the United States, Short (1984), Eraut (1994 and 1998), and Gonczi (1994) attempted to resolve tensions between two competing conceptions of competence: 'the ability to perform a set of behaviors' and 'a way of being'. They argue that the first conception has a very limited range of usefulness and applicability because competence is thought of as a thing or a set of acts that can be accomplished satisfactorily without any purpose, intent, thinking, or decision-making. Competence as a state of being is more holistic. According to this second conception, a person is either competent or incompetent. Either s/he/they have the integral, integrated dimensions of competence (including behaviors, performance, knowledge, skills, levels of sufficiency, intents, motives, attitudes, qualities, or states of being) or not. While this all-or-nothing conception of competence can also be thought of as reductionist, in that it ignores the issue of transfer of performance across practice contexts, it does represent the high-stakes licensing decisions made by professional regulating bodies.

Evaluations of competence often consider-and in some cases, attempt to resolve tensions between--evidence of observed performance in authentic practice contexts and more holistic judgments about personal attributes (e.g., that they take initiative, work well with others, etc.) (Hauer et al., 20I5) Eraut (1998, p. 134) suggests referring to personal attributes as "evidence of capability" rather than competence to acknowledge that a person may possess the capability to do more than they are deemed competent to perform through direct observation of workplace performance (Eraut, 1998).According to Gonczi (1994), competence is "conceived of as complex structuring of attributes needed for intelligent performance in specific situations" (p. 29). Professional judgment is essential to decide which combination of knowledge, skills, and abilities are needed for certain tasks to be performed in particular situations. The strength of Gonczi's (1994) conceptualization of competence is that it allows for the possibility that there may be more than one way of practicing competently in a particular context, and that ethics, values, and reflective practice are important considerations when making judgments about performance.

A popular contemporary definition of competence is the one advanced by Epstein and Hundert (2002): "The habitual and judicious use of communication, knowledge, technical skills, reasoning, emotions, values, and reflection in daily practice for the benefits of the individual and community being served" (p. 226-227).According to Epstein and Hundert (2002), competent professionals must have the acumen to initiate interventions appropriately and at the right time to help dependents (i.e., clients, children, patients) reach their goals. This definition has value in that it accounts for competence being linked to actual performance outcomes.

\section{THE RESEARCH PROBLEM}

Competence has long been described as a nebulous concept (Eraut, 1994; 1998; Short, 1984; Westera, 200 I) and to this day some confusion still exists over the fluid use of competence and its derivatives (competent, competency, and competencies), as well as what the standard of competence means (i.e., minimum proficiency or excellence) within and across professional education discourse, policy, and practice (Boyd et al., 20 I8; Pijl-Zieber et al., 20I4). For these reasons, competence has been contested as a viable construct for professional education (e.g., Norman, Norcini, \& Bordage, 20I4). However, competency-based education is increasingly being referred to as a 'global education policy' (Tromp, 2018). Internationally, professions are various stages of implementing entry-to-practice competence frameworks (e.g., Arakawa, Yamamura, Duggan \& Bates, 2019; Patel, Tonni, GadburyAmyot, van der Vleuten \& Escudier, 2018). Given the important nuances in the above conceptions of competence, it is possible to see how diverse professions - with diverse ways of thinking and approaches to solving complex problems - might begin to talk about this construct in different ways as they undergo educational reform. How professions conceptualize competence has implications for how competency-based education is operationalized within professional education programs at higher/tertiary institutions (Hager \& Butler, 1996).

The purpose of this study was to examine similarities and differences in how professional bodies conceptualize, describe, and represent competence within a sample of entry-to-practice competence frameworks. Specifically, this study seeks to answer the following research questions:

\section{How similar/different are professions, con- cerning:}

\author{
a. how their core competencies are de- \\ scribed; and
}

b. how their core competencies are related to one another (i.e., structurally organized)?

\section{To what extent are tensions between com- peting conceptions of competence conveyed within and across entry-to-practice compe- tence frameworks?}

\section{METHODS}

Competence frameworks are documents produced by regulating and accrediting bodies to create a shared mental model of performance standards at particular milestones along the professional career continuum (e.g., at entry-to-practice). Document analysis is the systematic procedure of finding, selecting, reviewing, and interpreting documents to uncover meaning and discover insights that are relevant to the research problem. The textual and graphic information contained within documents can provide context and understanding as to how particular groups of people think about particular phenomena and concepts, such as competence (Bowen, 2009).

\section{The Research Context}

This research was conducted within Ontario, Canada-the author's province and country of residence. In Canada, each province and territory maintains control over the licensing and regulation of professionals through their respective colleges (e.g., the Ontario College of Teachers, the Ontario Nurses Association, etc.). Similar to other developed counties, Canada has a national labor mobility agreement (i.e., the Agreement on Internal Trade): a federal policy, which is intended to support professionals and skilled workers with moving and practicing across national and 
international borders. Since this policy came into effect in the 1990s, professional competence frameworks have risen in popularity. They provide a means for multiple stakeholders involved in professional education and licensure to communicate and coordinate their quality assurance efforts more effectively (Kellermans, Floyd, Pearson, \& Spencer, 2008; Wu, Martin, \& Ni, 20I7).

Within professions, however, inconsistencies can still exist between provinces/territories with regards to the adoption of specific competence frameworks. This complicates professional program accreditation, as some academic programs in professional fields are subject to accreditation by professional bodies at the provincial, national, and even international levels (Universities Canada, n.d.). For some professional programs, this means ensuring that their curriculum, learning opportunities, and assessment plan align with multiple entry-to-practice competence frameworks. Having to contend with multiple conceptions of competence can be confusing and time-consuming-not only for educators but also for their students (Pijl-Zieber et al., 20l4).

Even though this research was chosen to be conducted in a Canadian context, the findings have relevance for anyone from any professional program, discipline, or field, who is engaged in competency-based teaching and learning. How competence is conceptualized and represented has implications for the design of curriculum, instruction, and assessment (Hager \& Butler, 1996). An understanding of how diverse professions describe and represent competence can inform future practice and scholarship aiming to enhance student learning within professional programs at higher/ tertiary education.

\section{Finding and Selecting the Documents for Analysis}

Current, publicly accessible entry-to-practice competence frameworks for ten diverse regulated professional disciplines were purposefully sampled, including Engineering, Law, Medicine, Nursing, Occupational Therapy, Pharmacy, Planning, Psychology, Social Work and Teaching (Table I). These professions were intentionally chosen for three reasons: (I) They are familiar to the general public, (2) They represent professions from diverse disciplines and professional sectors, and (3), They are professions requiring completion of a university degree before applying for registration/licensure. Given the tendency for professions to 'look in the mirror' (e.g., Forzani, 2014; Pijl-Zieber et al., 2014) or compare themselves only to like professions within their sector (i.e., comparing across health professions) (e.g., Wu, Martin, \& Ni, 2017), it was important to include a variety of frameworks from diverse disciplines within the sample for document analysis.

Data collection began by searching the Internet for entry-topractice competence frameworks prepared and used by national or provincial accrediting professional bodies. To do this, the search string "competenc* AND [profession] AND Canada" was used. Upon finding an entry-to-practice competence framework, the accrediting body's website was searched to locate the most up-todate accreditation information and resources. For professions with provincial accreditation, the provincial college's website was also searched to cross-reference the use/adherence to the same competence framework. The Ministère de l'Éducation, Gouvernement du Québec (MEQ) professional competence framework for teacher education was included in the sample because of its explicit reference to competencies for initial teacher educators. The Ontario College of Teachers' 'Standards of Practice' were excluded from the sample, as the framework is not based on competencies. Rather, the standards are stated as goals and aspirations guiding members of the teaching profession.

\section{Reviewing and Interpreting the Documents}

The language within these ten documents was analyzed through an iterative process using both content and inductive thematic analysis (Bowen, 2009). Content analysis is the process of identifying meaningful and relevant passages of text and organizing the information into categories that help to answer the research questions. Inductive thematic analysis is the process of looking for reoccurring ideas that emerge from the relevant text. All documents were imported into and coded using a qualitative data management/coding software (NVivo for Mac, version II.4.3). Analysis of each document involved successive rounds of skimming, reading, and meaning-making; progressively moving from more superficial examination to close reading of the text and word choice (Bowen, 2009).

\section{Content analysis}

The first round of analysis involved reading each document and identifying/flagging relevant passages of text. Using an excel spreadsheet, relevant information about each profession and their national or provincial entry-to-practice competence framework was extracted and recorded. Profession information included the name of the regulated profession, the name of the professional accrediting body, the university-based program(s) accredited (i.e., Bachelor, Professional, Masters, Doctorate), and important requirements for professional certification. The information recorded about the entry-to-practice competence framework included the title of the entry-to-practice framework, key language used to describe how competencies are organized within the document, and inclusion of core competencies related to disciplinary expertise, communication, interpersonal collaboration, scholarship, life-long learning, professionalism, leadership, management, and advocacy. Core competencies were organized according to these nine categories because they are domains often described as being important elements of professional practice. When any of the above information was missing from a framework/document, the word 'none' was inserted as a placeholder.

\section{Inductive thematic analysis}

Documents underwent a second round of more focused reading of the relevant content. During this phase, documents were reviewed by line, phrase, sentence, and paragraph segments, paying close attention to subtle cues in the language used to describe competence throughout each document. Research questions, as well as knowledge of the tensions between behavioral and integrated conceptions of competence (i.e., the conceptual framework), were used to identify units of meaning within the text. Important ideas emerging from the text became the initial set of codes. Coding was a back-and-forth interplay with the data, checking codes and concepts between documents (Bowen, 2009). Like Bowen (2009), codes were compared by posing two questions: (I) "How is this similar to or different from what is described in X document?" and (2) "What ideas are mentioned across all documents?" (p. 37). This approach of looking for similarities, differences, and general patterns within and across data sources is consistent with the Constant Comparative Method used in grounded theory research (Glaser \& Strauss, 1967). That said, the intention of this study was not to use insights from the data to start to build theory. Rather, the aim was to better under- 
stand similarities and differences in the ways different professions conceptualize, describe, and represent professional competence as a foundation for future research.

\section{FINDINGS}

Eight of the ten professions in the sample followed entry-to-practice competence profiles prepared by national associations or federations (Table I) and two were prepared by provincial regulating bodies (i.e., a professional college and a provincial government) Provincial-level accreditation suggests potential disagreement about what constitutes competence across provinces and/or concerns regarding the adoption of a competency-based approach to professional education within the profession.

\begin{tabular}{|c|c|c|}
\hline \multicolumn{3}{|c|}{$\begin{array}{l}\text { Table I. Entry-to-practice competence frameworks prepared by } \\
\text { national or provincial professional bodies }\end{array}$} \\
\hline Profession & $\begin{array}{l}\text { National or provincial } \\
\text { Professional Body }\end{array}$ & $\begin{array}{l}\text { Entry-to-Practice Compe- } \\
\text { tence Profile }\end{array}$ \\
\hline Engineering & Engineers Canada & Graduate Attributes (2017) \\
\hline Law & $\begin{array}{l}\text { Federation of Law Societies } \\
\text { of Canada }\end{array}$ & $\begin{array}{l}\text { National Competency } \\
\text { Requirements (2018) }\end{array}$ \\
\hline Medicine & $\begin{array}{l}\text { Royal College of Physicians } \\
\text { and Surgeons of Canada } \\
\text { (RCPSC) }\end{array}$ & $\begin{array}{l}\text { CanMEDS } 2015 \text { Physician } \\
\text { Competency Framework }\end{array}$ \\
\hline Nursing & $\begin{array}{l}\text { College of Nurses of Ontar- } \\
\text { io }(\mathrm{CNO})\end{array}$ & $\begin{array}{l}\text { Competencies for En- } \\
\text { try-Level Registered Nurse } \\
\text { Practice (2014) }\end{array}$ \\
\hline $\begin{array}{l}\text { Occupational } \\
\text { Therapy }\end{array}$ & $\begin{array}{l}\text { Canadian Association of } \\
\text { Occupational Therapists } \\
\text { (CAOT) }\end{array}$ & $\begin{array}{l}\text { Profile of Practice of } \\
\text { Occupational Therapists in } \\
\text { Canada }(20 \mid 2)\end{array}$ \\
\hline Pharmacy & $\begin{array}{l}\text { Association of Faculties of } \\
\text { Pharmacy of Canada (AFPC) }\end{array}$ & $\begin{array}{l}\text { AFPC Educational Out- } \\
\text { comes for First Professional } \\
\text { Degree Programs in Phar- } \\
\text { macy in Canada (2017) }\end{array}$ \\
\hline Planning & $\begin{array}{l}\text { Canadian Institute of Plan- } \\
\text { ners (CIP) }\end{array}$ & $\begin{array}{l}\text { Competency Standards for } \\
\text { the Planning Profession in } \\
\text { Canada (20I0) }\end{array}$ \\
\hline Psychology & $\begin{array}{l}\text { Canadian Psychological } \\
\text { Association (CPA) }\end{array}$ & $\begin{array}{l}\text { Mutual Recognition } \\
\text { Agreement (2004) specifying } \\
\text { Core Competencies for the } \\
\text { Practice of Psychology in } \\
\text { Canada }\end{array}$ \\
\hline Social Work & $\begin{array}{l}\text { Canadian Council of Social } \\
\text { Work Regulators (CCSWR) } \\
\text { Canadian Association for } \\
\text { Social Work Education } \\
\text { (CASWE) }\end{array}$ & $\begin{array}{l}\text { Entry-Level Competency } \\
\text { Profile for the Social Work } \\
\text { Profession in Canada (20I2) } \\
\text { Standards for Accreditation } \\
\text { (20I4) specifying Core } \\
\text { Learning Objectives }\end{array}$ \\
\hline Teaching & $\begin{array}{l}\text { Gouvernement du Québec, } \\
\text { Ministère de l'Éducation }\end{array}$ & $\begin{array}{l}\text { Reference Framework for } \\
\text { Professional Competencies } \\
\text { in the Teaching Profession } \\
(200 \mathrm{I})\end{array}$ \\
\hline
\end{tabular}

A summary of each profession's entry-to-practice profile is provided as a supplementary appendix. These summaries highlight how each professional body conceptualizes competence through the types of language/terms used to articulate the scope of practice and the standard expected at entry-to-practice.A comparison of conceptions across professions' entry-to-practice frameworks is presented. Illustrative examples, comparing conceptions of competence, and language communicating a tension between two opposing conceptions, are provided. Finally, similarities and differences in the presence/absence of core competencies are identified and discussed.

\section{Comparing Conceptions of Competence Across Professions' Entry-to-Practice Frameworks}

As illustrated in Table 2, the language used to describe competence and the standard of competence across professional entryto-practice frameworks is inconsistent. While all professions agree that competence includes a set of specific knowledge/understandings and skills/abilities, four of the professions also include attitudes/values (i.e., Medicine, Planning, Social Work, and Teaching) and one profession explicitly includes judgment (i.e., Nursing). Further, in describing the standard of competent performance, seven of the professions describe a "minimum expectation" of "safe and effective practice," which includes being 'ethical' and 'efficient' (i.e., Nursing, Occupational Therapy, Pharmacy, Planning, Psychology, Social Work, and Teaching).Whereas Medicine, Nursing, and Teaching use language suggesting criterion-referenced standards, Engineering explicitly describes a norm-referenced standard: "to a degree that would be acceptable by professional engineers who are familiar with undergraduate engineering education in Canada (Engineers Canada, 2017, p.79). Law is the only profession that does not articulate a standard of competence as part of their entry-to-practice requirements.

Perhaps the most interesting finding was that six of the ten professions describe a relational architecture between meta-competencies (i.e., roles, competency categories, competency blocks) and component key and enabling competencies. And, of these six professions, Occupational Therapy and Pharmacy have modeled their architecture off of the CanMEDS 2005 or 2015 Physician Competency Framework (i.e., Medicine). Nursing, Social Work, and Teaching have their architectural frameworks depicting an ongoing cycle of services, a layered pyramid, and a layered diamond of competencies, respectively. These architectures-overlapping petals (i.e., CanMEDS), cycles (i.e., Nursing), pyramids (i.e., Social Work), and diamonds (i.e., Teacher Education in Quebec) — reveal the extent to which competencies are perceived to be interrelated. Engineering, Law, Planning, Psychology - the four professions without any relational architecture-demonstrate a more reductionist conception, in which competence is described within lists of knowledge/understandings and skills/abilities and attitudes with little to no explicit relationship with one another. This is except for Psychology, which describes 'Interpersonal Relationships' as being the foundational or "basic competency [which] forms part of all the other competencies" (MRA, 2004, p. 8).

\section{Comparative examples illustrating differences in professional conceptions of competence.}

As an illustrative example, it is useful to compare how competence is described in Nursing and Engineering. According to the CNO (20I4), "Safe and ethical registered nursing practice requires the assessment, integration, and performance of many competencies at the same time. It is also dependent on the specific practice context and client needs for which the competencies are to be applied" (p.4) A Registered Nurse is said to use their "knowledge, skill, judgment, attitudes, values and beliefs to perform in a given role, situation and practice setting" (p. I I). Conversely, Engineering Canada (2017) requires graduates of a professional engineering program to "possess attributes under 12 headings: (I) A knowledge base for engineering; (2) Problem analysis; (3) Investigation; (4) Design; (5) Use of engineering tools; (6) Individual and teamwork; (7) Communication skills; (8) Professionalism; (9) Impact 


\begin{tabular}{|c|c|c|c|}
\hline \multirow[t]{2}{*}{ Profession } & \multicolumn{2}{|c|}{ Descriptive Language } & \multirow{2}{*}{ Relational Architecture } \\
\hline & Competence & Standard & \\
\hline Engineering & $\begin{array}{l}\text { Graduate Attributes } \\
\text { Knowledge/Understanding and Abilities }\end{array}$ & $\begin{array}{l}\text { "To a degree that would be acceptable by } \\
\text { professional engineers who are familiar with } \\
\text { undergraduate engineering education in } \\
\text { Canada" (Engineers Canada, 20I7, p.79) }\end{array}$ & None \\
\hline Law & $\begin{array}{l}\text { Competency Requirements } \\
\text { Knowledge/Understanding and Abilities }\end{array}$ & None & None \\
\hline $\begin{array}{l}\text { Medicine } \\
\text { (Specialty) }\end{array}$ & $\begin{array}{l}\text { Roles, key competencies, enabling compe- } \\
\text { tencies } \\
\text { Knowledge, skills, and attitudes }\end{array}$ & $\begin{array}{l}\text { Entrustment of professional activities } \\
\text { through milestones, describing "the expected } \\
\text { ability of a healthcare professional at a stage } \\
\text { of expertise" (CanMEDS 20I5, p. } 7 \text { ) }\end{array}$ & $\begin{array}{l}\text { CanMEDS } 2015 \text { Framework: the central role } \\
\text { of Medical Expert; supported by } 6 \text { intrinsic } \\
\text { roles: Communicator, Collaborator, Leader, } \\
\text { Health Advocate, Scholar and Professional }\end{array}$ \\
\hline Nursing & $\begin{array}{l}\text { Broad competency categories } \\
\text { Knowledge, skills, ability, and judgment }\end{array}$ & $\begin{array}{l}\text { "The demonstration of integrated knowledge, } \\
\text { skills, abilities, and judgment required to } \\
\text { practice nursing safely and ethically" (CNO, } \\
20 \mid 4, \text { p.II) }\end{array}$ & $\begin{array}{l}\text { Ongoing cycle of } 5 \text { broad Competency Cat- } \\
\text { egories with the client/recipient of nursing } \\
\text { services at the center of the circle }\end{array}$ \\
\hline $\begin{array}{l}\text { Occupational } \\
\text { Therapy }\end{array}$ & $\begin{array}{l}\text { Roles, key competencies, enabling compe- } \\
\text { tencies } \\
\quad \text { Knowledge, skills, and abilities }\end{array}$ & $\begin{array}{l}\text { "Meet or exceed minimal performance ex- } \\
\text { pectation for safe and effective occupational } \\
\text { therapy practice" (Canadian Association of } \\
\text { Occupational Therapists, 20I2, p. I5) }\end{array}$ & $\begin{array}{l}\text { Adapted CanMEDS } 2005 \text { Framework: the } \\
\text { central role of the OT as an expert in } \\
\text { enabling occupation, surrounded by } 6 \text { sup- } \\
\text { porting roles: Communicator, Collaborator, } \\
\text { Practice Manager*, Change Agent*, Scholarly } \\
\text { Practitioner* and Professional }\end{array}$ \\
\hline Pharmacy & $\begin{array}{l}\text { Educational Outcomes: Roles, key competen- } \\
\text { cies, enabling competencies } \\
\text { Knowledge and skills }\end{array}$ & $\begin{array}{l}\text { "To provide safe, effective, efficient health } \\
\text { care" (Association of Faculties of Pharmacy } \\
\text { of Canada, 2017, p. 12) }\end{array}$ & $\begin{array}{l}\text { Adapted CanMEDS } 2015 \text { Framework: the } \\
\text { central role/identity of Care Provider; } \\
\text { supported by } 6 \text { intrinsic roles: Communica- } \\
\text { tor, Collaborator, Leader-Manager,* Health } \\
\text { Advocate, Scholar and Professional }\end{array}$ \\
\hline Planning & $\begin{array}{l}\text { Realms of competence: Functional and En- } \\
\text { abling Competencies; each with sub-domains } \\
\text { Knowledge, skills, and attitudes }\end{array}$ & $\begin{array}{l}\text { "the capacities required of a planner to prac- } \\
\text { tice effectively, professionally, and ethically" } \\
\text { (Canadian Institute of Planners, } 2010, \text { p. } 6 \text { ) }\end{array}$ & None \\
\hline Psychology & $\begin{array}{l}\text { Core Competencies } \\
\text { Knowledge and skills }\end{array}$ & None & None \\
\hline Social Work & $\begin{array}{l}\text { Competency blocks; each with families of } \\
\text { key global competencies and sub-compe- } \\
\text { tencies } \\
\text { Knowledge, skills, and abilities } \\
\text { Core learning objectives } \\
\text { Values, knowledge, and skills }\end{array}$ & $\begin{array}{l}\text { "the competencies required to engage in safe } \\
\text { and effective practice" (Canadian Council of } \\
\text { Social Work Regulators, } 2012 \text {, p. 6) }\end{array}$ & $\begin{array}{l}\text { A pyramid with personal competencies } \\
\text { (empathy, integrity, etc.) at the base upon } \\
\text { which one builds general competencies (lit- } \\
\text { eracy, critical thinking, etc.), and entry-level } \\
\text { professional competencies (organized into } \\
\text { competency blocks). }\end{array}$ \\
\hline Teaching & $\begin{array}{l}\text { Categories of core professional competen- } \\
\text { cies; each with a set of features and mastery } \\
\text { criteria } \\
\quad \text { Knowledge, skills, attitudes }\end{array}$ & $\begin{array}{l}\text { "a professional competency involves a suc- } \\
\text { cessful, effective, efficient, recurrent ability to } \\
\text { act" (MEQ, 200I, p.43) } \\
\text { "The level of mastery refers to what can } \\
\text { reasonably be expected of a newly graduat- } \\
\text { ed teacher (MEQ, 200I, p. 53) }\end{array}$ & $\begin{array}{l}\text { Diamond with } 3 \text { levels: Foundations inform- } \\
\text { ing Teaching Act and Social and Educational } \\
\text { Context, which inform Professional Identity }\end{array}$ \\
\hline
\end{tabular}

of engineering on society and the environment; (10) Ethics and equity; (I I) Economics and project management; and (I2) Lifelong learning. Knowledge/understanding and skills/abilities are listed as separate items to be assessed "using assessment tools that are appropriate to the attribute" (p. I5) and competence is "a specified set of skills, values, and competencies (attributes) to each and every graduating class" (Engineers Canada, 2017, p. 79). Whereas in Nursing, competence is described as having the attributes needed for intelligent performance in specific situations and is attributed to individual performance. Using professional judgment, Nurses decide which combination of knowledge, skills, and abilities are needed for certain tasks to be performed safely and effectively in particular situations.

Likewise, in the context of Teaching, the MEQ (200I) explains that:

Competent people, in the heat of the action, must be able to recognize the demands and constraints of the situation, identify the available resources and take action by incorporating, combining, and orchestrating those resources in a way that is relevant to and effective for the situation at hand. Competency, therefore, lies in the ability to [...] read a situation in a certain way, give it meaning and, where necessary, adapt, invent or improvise to deal with it (p. 49).

But, even within those professions that appear to hold a more holistic conception of competence, and emphasize the role of professional judgment in knowing when to draw upon certain values, knowledge, and skills, there is still evidence of reductionist thinking. Consider Medicine as an illustrative example.

According to CanMEDS 2015, as Medical Experts, physicians "integrate all of the CanMEDS Roles, applying medical knowledge, clinical skills, and professional values in their provision of high-quality and safe patient-centered care. Medical Expert is the central physician Role in the CanMEDS Framework and defines the physician's clinical scope of practice" (p. 14). However, in describing the revisions made from 2005 to the 2015 edition of the CanMEDS Framework, Frank et al. (2015) explain that "Concepts that are relevant to multiple roles will be articulated in the role where they are the most prominent. Although redundancy and overlap are accepted and even expected, the framework itself will avoid repetition while ensuring the appropriate integration of roles" ( $p$. 6). Frank et al. (20I5) went on to explain how "areas of overlap between roles are minimized, resulting in a $3.5 \%$ decrease in the 
number of key competencies and a $29.4 \%$ decrease in the number of enabling competencies; although aspects of a shared plan of care may pertain to more than one role, the competencies of a given role are written specifically for that role alone" (p. I0). This was in response to physician stakeholders who, during focus group consultations, "urge[d] [authors] to try and organize issues in one category only, to avoid duplication and repetition [because] this will assist with applying this framework, e.g. tracking data, creating templates, providing feedback, creating practice improvement plans, and [facilitating] Continuing Professional Development" ( $p$. II). This quote suggests that even when "competencies are integrated into a seamless whole and reflect the daily activities of the [professional]" (CanMEDS 20I5, p. 28), reductionism inevitably comes with trying to accurately and reliably assess the capacity of the 'whole' professional to perform across contexts.

\section{Comparing Professions Based on their Inclusion of Core Competencies}

As illustrated in Table 3, each of the ten professions explicitly describes core competencies related to disciplinary expertise and ethics and professionalism. Except for Law and Psychology, professions describe communication, collaboration, lifelong learning and management competencies-some more explicitly than others. It is the inclusion of scholarship, leadership, and advocacy which seems to differentiate these professions. Medicine and Pharmacy, Engineering and Teaching, and Social Work and Nursing describe competencies within similar domains. Law stands out as having the fewest number of domains.

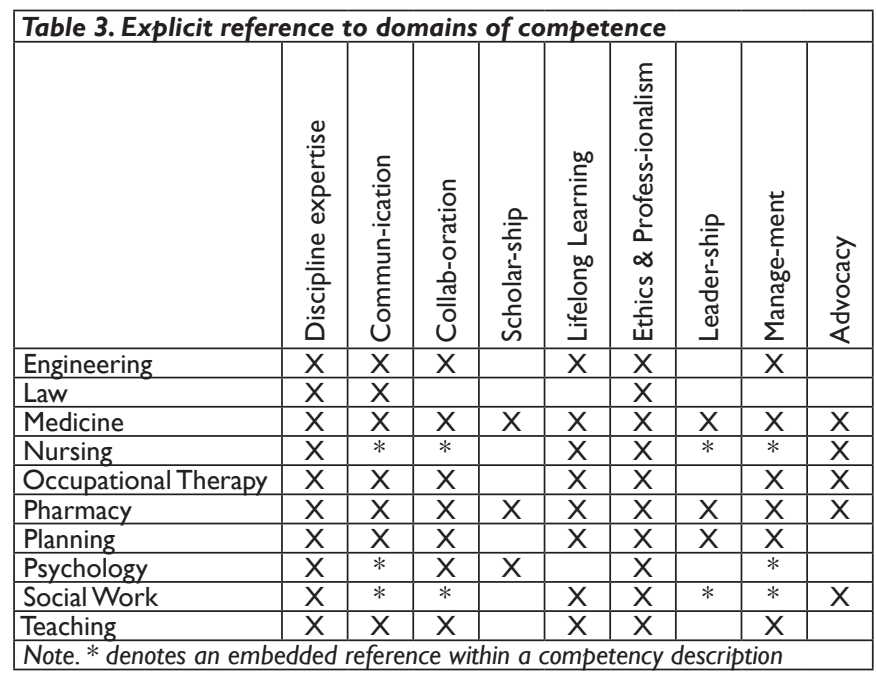

Within competence domains, professions describe common competencies (Table 4). When professions describe disciplinary expertise, they are referring to the application of knowledge and skills to be able to assess clients, identify problems, recognize the limits of their scope of practice, establish an intervention/management plan for their client, perform procedures/deliver services, and attention to continuous quality improvement. Similarly, across professions, competencies related to ethics and professionalism include the knowledge, skills, and attitudes needed to adhere to standards of practice/rules of conduct, be aware of social inequities and power differentials, make ethical decisions, demonstrate responsibility to clients, and contribute to professional regulation. Medicine, Pharmacy, and Psychology emphasize the competencies related to advancing knowledge through the engagement in, and dissemination of, research. Except for Psychology, the health professions describe competencies related to advocating for individual clients and the needs of communities and populations. In professions that articulate leadership as a separate domain (i.e., Medicine, Pharmacy and Planning), competencies describe leading a team. Conversely, in professions that embed leadership under alternative domains (e.g., Nursing and SocialWork) competencies describe coordinating services and supporting a team.

\section{Summary}

The review of the 10 competence frameworks revealed that although professions describe similar core competencies, which can be organized across 'expert' and supporting/intrinsic domains (including communication; interpersonal collaboration; lifelong learning; ethics and professionalism; and management), differences exist in the extent to which different professions include leadership, advocacy, or scholarship competencies. Systematic differences also exist in the organization of the entry-to-practice competence frameworks. Professions that organized core competencies according to 'roles' or 'meta-competencies' (i.e., Medicine, Nursing, Occupational Therapy, Pharmacy, Social Work and Teaching) describe competence as being more integrated, holistic, and equal to more than the sum of its components. Whereas the professions without this organizing structure of integrated meta-competencies (i.e., Engineering, Law, Planning and Clinical Psychology) describe competence as being equal to the sum of its components: either behavioral/performance-like lists of attributes, or groups of knowledge, skills, and ethical/professional values.

\begin{tabular}{|l|l|}
\hline Table 4. Common competencies included within each domain \\
\hline $\begin{array}{l}\text { Dompetence } \\
\text { Domains }\end{array}$ & $\begin{array}{l}\text { Assessment/problem identification and analysis; scope of } \\
\text { practice/limits; establishing an intervention/ manage- } \\
\text { ment plan; performing procedures/delivering services; } \\
\text { and continuous improvement of quality }\end{array}$ \\
\hline Communication & $\begin{array}{l}\text { Written and electronic documentation; reading/visual } \\
\text { interpretation; oral speaking; listening and dialogue; } \\
\text { interpersonal relationships }\end{array}$ \\
\hline Collaboration & $\begin{array}{l}\text { Intra-professional; inter-professional; conflict manage- } \\
\text { ment; handover of care; and trust }\end{array}$ \\
\hline Scholarship & $\begin{array}{l}\text { Advance knowledge/engage in research and dissemina- } \\
\text { tion }\end{array}$ \\
\hline $\begin{array}{l}\text { Lifelong } \\
\text { Learning }\end{array}$ & $\begin{array}{l}\text { Maintain and enhance competence/reflective practice; } \\
\text { professional development; facilitate learning of others }\end{array}$ \\
\hline Ethics \& & $\begin{array}{l}\text { Adherence to standards of practice/rules of conduct; } \\
\text { awareness of inequity and power differentials; ethical } \\
\text { Professionalism } \\
\text { decision-making; responsibility to clients and society; } \\
\text { contribution to professional regulation }\end{array}$ \\
\hline Leadership & $\begin{array}{l}\text { Contribute to system improvement of service delivery; } \\
\text { vision; responsiveness and influence }\end{array}$ \\
\hline Advocacy & $\begin{array}{l}\text { Manage daily professional practice (i.e., business and } \\
\text { finances, project management, management of others; } \\
\text { stewardship of resources; career planning }\end{array}$ \\
\hline $\begin{array}{l}\text { Advocate for individual clients; advocate for the needs } \\
\text { of communities and populations }\end{array}$ \\
\hline Management
\end{tabular}

\section{DISCUSSION}

This examination of entry-to-practice competence frameworks across ten diverse professions offers important insights into our understanding of competence as a construct, which can inform pedagogical decision-making and scholarship on teaching and learning. There are two important findings of this research. First, this study suggests that even though professions are unique in their technical knowledge and skills, they are quite similar in 
the supporting/intrinsic domains that enable technical performance (i.e., communication; interpersonal collaboration; ethics and professionalism; lifelong learning; and management). Competencies within these domains, which are often described as being 'professional skills' or 'soft-skills,' are not to be taken lightly, as they are what enable professionals to provide human-elements to technical performance (e.g., Davies, McMeel \&Wilkinson, 20 I5; Fransson, Gallant, \& Shanks, 2018).

While there is merit to distinguishing professions based on their unique technical abilities for addressing different societal problems (i.e., education, urban and regional planning, social assistance, medical care, etc.) and for delineating scope of practice, there is also value in recognizing how professions are similar and interconnected (Susskind \& Susskind, 20I5). Knowing that competence integrates discipline-specific technical knowledge and skills with shared intrinsic/supporting competencies may help persuade professions - who often educate in silos - to look outside of their discipline when considering approaches to instruction and assessment. For example, professional programs may consider forming intra-institutional partnerships and research collaborations to investigate approaches to common challenges with assessing competence. It is important to recognize that these suggestions for collaboration are important yet controversial, given the longstanding conflicts and contests amongst the professional groups for status, power, and remuneration-ultimately contributing to hierarchical relationships amongst the different disciplines within higher education institutions (Bucher, Chreim, Langley \& Reay, 2016).

As a second key finding, this research also suggests that tensions between conceptions of competence within the professional literature (Eraut, 1994, 1998; Gonczi, 1994; Short, 1984) manifest as architectural differences amongst the entry-to-practice competence frameworks. Professions organizing competencies according to 'meta-competency' domains describe competence as being more integrated within a central expert role. More integrated architectures (e.g., overlapping petals [representing intrinsic/supporting domains] of the CanMEDS [20I5] flower, which enable medical expert performance; CCSWR's [20I2] layered pyramid of personal, general, entry-level and advanced practice competencies; etc.) reflect a system in which competence is represented as being more than the sum of its component competencies. Whereas professions conceptualizing competence as being equal to the sum of its components represent competence as a collective list of competencies organized according to categories of knowledge, skills, and ethical/professional values. In these professions, the lack of relational architecture suggests a more fragmented conception of competence.

Hager and Gonczi (1996) suggest that how competence is conceptualized has implications for how competence standards are used and assessed in practice. This research goes one step further in suggesting that how competence is described and architecturally represented has implications for the ways in which entry-to-practice competence frameworks are operationalized by professional education programs on the ground; including the organization of curriculum, offering of teaching and learning opportunities, as well as the approach to the assessment and evaluation of competence. However, in looking at prior literature to inform these hypotheses, there is a lack of research investigating the relationship between conceptions, representations (frameworks), and operationalizations of entry-to-practice competence.
This is not surprising given that competency-based professional education is an emerging field of educational research. Therefore, the findings from this initial document analysis of entry-topractice competence frameworks provide a critical starting point to inform future scholarship exploring the approaches diverse professional education programs are using to operationalize entry-to-competence frameworks across professional contexts.

\section{Extrapolating Approaches to Operationalization}

When competence is conceptualized as an integrated and holistic construct, competence should be represented as a "complex structuring of attributes needed for intelligent performance in specific situations" (Gonczi, 1994, p. 29) for reasons of constructive alignment (Biggs, 1996). The related and supporting meta-competencies should work together to enable competent technical performance within and across practice contexts. It follows that the architecture of the entry-to-practice competence framework should reflect a relational system in which competence is more than the sum of its components. In operationalizing such a framework in practice, one would imagine a program with an integrated curriculum and authentic teaching and learning opportunities where professional candidates can practice using their professional judgment in context(s) and apply relevant meta-competencies in concert to enable competent performance. Examples of authentic competency-based teaching and learning opportunities may include active participation in case studies, simulations, and work-integrated learning (e.g., co-op placements, practicums, or internships), in which candidates are directly observed and assessed based on their demonstration of performance (Koenen, Dochy \& Berghmans, 20I5). High-stakes decisions about the achievement of competence would be made based on patterns of performance over time, as documented by multiple assessors through multiple low-stakes assessments conducted across practice contexts (Gruppen et al., 20l8).

In contrast, when competence is conceptualized as being equal to the sum of its components, competence is likely represented as collective lists of knowledge, skills, and ethical/professional values. In operationalizing such a framework, one would expect that individual knowledge, skills, and ethical/professional values would be mapped to individual courses, which focus on topics or groups of related knowledge and their practical applications. Complementary to these more theoretical/knowledge-based courses may be supervised work-integrated learning courses (e.g., labs, co-op placements, practicums), which focus on the development and assessment of more technical skills. Assessment tasks and tools would be designed to measure performance on a discrete set of competencies tagged to each specific course. High-stakes decisions about the achievement of competence would be based on whether or not each student has passed all of the required courses for program completion.

These examples serve to highlight differences in the two extremes. In reality, most professional programs are likely a hybrid of integrated/holistic and component approaches to operationalization, combing courses and dedicated opportunities for more authentic learning opportunities and assessment in the field (i.e., field placements, internships, etc.) (Koenen et al., 20I5). A combined approach likely reflects programs' practical need to abide by the credit hour and service requirements set by accreditation and university policies. The credit hour is well known to be a barrier to innovation and change in higher education; including 
implementation of competency-based approaches to teaching and learning (e.g.,Armstrong, 2016; Lacey \& Murray, 20I5; Pichette \& Watkins, 2018)

\section{When Moving Forward, Remembering Not to Lose Sight of the Past}

As we have learned from prior competency-based initiatives, most notably the failure of the Competency-Based Teacher Education movement in the United States, reducing a profession, and thus, a professional program, to seemingly endless lists of 'component' knowledge and skills-simply because the behavioral indicators are more specific, observable, and measurable-is problematic (Gitlin, 1981; Piper \& Houston, 1980). Not only is it challenging from a feasibility perspective to assess and monitor the development of so many individual behaviors, but the validity of what is being assessed is also called into question. Individual competencies measured in isolation do not guarantee that a professional candidate can integrate the competencies that are needed to deliver safe and effective services consistently across practice contexts. For this reason, some professional programs are looking to develop learning outcomes in the form of Entrustable Professional Activities (EPAs), which represent what professionals do in practice and require the integration of multiple competencies (e.g., Chesbro, Jensen, \& Boissionnault, 20I7; ten Cate, 20I3).

\section{CONCLUSION: LIMITATIONS AND CONTRIBUTIONS}

In summary, entry-to-practice competence profiles are documents produced internationally by professional organizations to communicate a shared vision of the knowledge/understanding, skills/abilities, values, and judgments expected of graduates who have been granted the privilege of transitioning to more independent professional practice. The language and architecture used to represent entry-to-practice competence are important for creating a shared mental model of performance standards to be used by professional education stakeholders (i.e., students, educators, workplace supervisors, interprofessional colleagues, and clients) when making decisions about education, service provision, and client safety (Wu, Martin \& Ni, 20l7). The current work is limited by its focus on a small, purposeful sample of documents, which continue to evolve and be revised as professions' conceptions of competence continue to take shape. Nevertheless, this study highlights tensions in conceptualizing and representing competence as an integrated whole or summation of component knowledge, skills, and ethical/professional values. This work provides a critical starting point upon which to launch future research investigating how professional conceptions of competence and entry-topractice competence frameworks are informing programmatic decision-making within professional education programs at higher education/tertiary institutions internationally.

\section{Acknowledgements}

The author would like to acknowledge Dr. Don Klinger, Dr. Sue Fostaty Young, and Dr. Catherine Donnelly for their insights in contributing to the revisions of this manuscript.

\section{REFERENCES}

Arakawa, N., Yamamura, S., Duggan, C., \& Bates, I. (20I9). The development of a foundation-level pharmacy competency framework:An analysis of country-level applicability of the Global Competency Framework. Research in Social and Administrative Pharmacy, https://doi.org/10.1016/j. sapharm.2019.06.007

Armstrong, L. (20I6). Barriers to innovation and change in higher education. TIAA-CREF Institute. Retrieved from https:// www.tiaainstitute.org

Association of Faculties of Pharmacy of Canada. (2017). Educational Outcomes for First Professional Degree Programs in Pharmacy in Canada. Retrieved from http://www.afpc.info

Biggs, J. (1996). Enhancing teaching through constructive alignment. Higher education, 32(3), 347-364.

Bowen, G.A. (2009). Document analysis as a qualitative research method. Qualitative Research Journal, 9(2), 27-40.

Boyd,V.A., Whitehead, C. R., Thille, P., Ginsburg, S., Brydges, R., \& Kuper,A. (2018). Competency-based medical education: the discourse of infallibility. Medical Education, 52, 45-57.

Bucher, S.V., Chreim, S., Langley, A., \& Reay, T. (2016). Contestation about collaboration: Discursive boundary work among professions. Organization Studies, 37(4), 497-522.

Canadian Association for Social Work Education. (20I4). Standards for Accreditation. Retrieved from https://caswe-acfts.ca

Canadian Association of Occupational Therapists. (20I2). The Profile of Practice of Occupational Therapists in Canada. Retrieved from https://www.caot.ca

Canadian Council of Social Work Regulators. (2012). Entry-Level Competency Profile for the Social Work Profession in Canada. Retrieved from http://www.ccswr-ccorts.ca/

Canadian Institute of Planners. (2010). Competency Standards for the Planning Profession in Canada. Retrieved from https:// www.cip-icu.ca

Canadian Psychological Association. (2004). Mutual Recognition Agreement. Retrieved from https://cpa.ca

Chesbro, S. B., Jensen, G. M., \& Boissonnault,W. G. (2017). Entrustable Professional Activities as a Framework for Continued Professional Competence: Is Now the Time?. Physical Therapy, 98(I), 3-7.

College of Nurses of Ontario. (2014). Entry-to-practice competencies. Retrieved from https://www.cno.org

Competency-Based Education Network (C-BEN). (2017). Quality Principles and Standards for Competency-Based Education Programs. Retrieved from http://www.cbenetwork.org/

Davies, K., McMeel, D., \& Wilkinson, S. (October, 20I5). Soft skill requirements in a BIM project team. Proceedings of the 32ns CIB W78 Conference. Eindhoven, the Netherlands.

Engineers Canada. (2017). Accreditation Criteria and Procedures. Canadian Engineering Accreditation Board. Retrieved from https://engineerscanada.ca

Epstein, R. M., \& Hundert, E. M. (2002). Defining and assessing professional competence. Journal of the American Medical Association, 287(2), 226-235.

Eraut, M. (1994). Developing Professional Knowledge and Competence. Falmer Press, London.

Eraut, M. (1998). Concepts of Competence. Journal of Interprofessional Care, I2(2), I27-139.

Federation of Law Societies of Canada. (2018). National Requirement. Retrieved from https://flsc.ca 
Forzani, F. M. (20|4). Understanding "core practices" and "practice-based" teacher education: learning from the past. Journal of Teacher Education, 65(4), 357-368.

Frank, J. R., Snell, L., \& Sherbino, J. (eds.). CanMEDS 2015 Physician Competency Framework. Ottawa: Royal College of Physicians and Surgeons of Canada. Retrieved from http:// www.royalcollege.ca

Fransson, G., Gallant, A., \& Shanks, R. (20I8). Human elements and the pragmatic approach in the Australian, Scottish, and Swedish standards for newly qualified teachers. Journal of Educational Change, 19, 243-267.

Gitlin,A. (198I). Horizontal evaluation:An approach to student teacher supervision. Journal of Teacher Education, XXXII (5), 47-50.

Glaser, B. G., \& Strauss, A. (1967). The Discovery of Grounded Theory. Chicago:Adeline.

Gonczi, A. (1994). Competency-based assessment in the professions in Australia. Assessment in Education, I ( I), 27-44.

Hager, P., \& Butler, J. (1996). Two models of educational assessment. Assessment \& Evaluation in Higher Education, 2 I (4), 367-378.

Hager, P. \& Gonczi, A. (1996).What is competence? Medical Teacher, I8(I), I5-18.

Holmboe, E. S.,Ward, D. S., Reznick, R. K. et al. (20I I). Faculty development in assessment:The missing link in competency-based medical education. Academic Medicine, 86(4), 460-467.

Hoyle, E. \& John, P. (1995). Professional knowledge and professional practice. London: Cassell.

Koenen, A., Dochy, F., \& Berghmans, I. (20I5). A phenomenographic analysis of the implementation of competence-based education in higher education. Teaching and Teacher Education, 50, I-12.

Lacey,A., \& Murray, C. (20I5). Rethinking the Regulatory Environment of Competency-Based Education.AEI Series on Competency-Based Higher Education. American Enterprise Institute for Public Policy Research.

Martinet, M.A., Raymond, D., \& Gauthier, D. (200I). Teacher Training: Orientations and Professional Competencies. Gouvernement du Québec, Ministère de l'Éducation. Bibliothèque nationale du Québec.

Norman, G., Norcini, J., \& Bordage, G. (20I4). Competency-Based Education: Milestones or Millstones'? Journal of Graduate Medical Education, doi: http://dx.doi.org// 0.4300/ JGME-D-I3-00445. I

Patel, U. S., Tonni, I., Gadbury-Amyot, C., Van der Vleuten, C. P. M., \& Escudier, M. (2018). Assessment in a global context: An international perspective on dental education. European Journal of Dental Education, 22, 21-27.
Pichette, J.,Watkins, E. K. (2018) Competency-based Education: Driving the Skills-measurement Agenda. Toronto: Higher Education Quality Council of Ontario.

Pijl-Zieber, E. M., Barton, S., Konklin, J., Awosoga, O., \& Craine,V. (20I4). Competence and competency-based nursing education: Finding our way through the issues. Nurse Education Today, 34, 676-678.

Piper, M. K., \& Houston, R.W. (1980). The search for teacher competence: CBTE and MCT. Journal of Teacher Education, $3 I(5), 37-40$.

Rich, J.V. (2017). Proposing a model of co-regulated learning for graduate medical education. Academic Medicine, 92(8), II00-1104.

Shaw, K., Cassel, C. K., Black, C., \& Levinson,W. (2009). Shared medical regulation in a time of increasing calls for accountability and transparency: Comparison of recertification in the United States, Canada, and the United Kingdom. Journal of the American Medical Association, 302( I8), 2008-20I4.

Short, E. C. ( 1 984). Competence reexamined. Educational Theory, 34(3), 20I-207.

Susskind, R., \& Susskind, D. (20I5). The Future of Professions: How Technology will Transform the Work of Human Experts. New York, NY: Oxford University Press.

ten Cate. (20I3). Competency-based education, Entrustable professional activities, and the power of language. Journal of Graduate Medical Education, 5( I), 6-7.

Tromp, R. (2018). Global Policies, Local Meanings:The Re-Contextualization of Competency-Based Education Reforms in Mexico. In A.Verger, H. K. Altinyelken, \& M. Novelli (eds.), Global Education Policy and International Development (p. 16I-184). New York: Bloomsburry Academic.

Tuxworth, E. (1989). Competence based education and training: background and origins. In J.W. Burke (ed.), Competency Based Education and Training (p. 10-25). London: Falmer Press.

Universities Canada. (n.d.). Professional programs accreditation. Retrieved from https://www.univcan.ca/universities/quality-assurance/professional-programs-accreditation/

Wu, W. , Martin , B. C , \& Ni , C. (2017). A systematic review of competency-based education effort in the health professions: Seeking order out of chaos. In K. Rasmussen, P. Northrup, \& R. Colson. (Eds.), Handbook on research on competency-based education in university settings (Pp. 352 378 ). Hershey, PA: IGI Global.

Westera,W. (200I). Competences in education:A confusion of tongues. Journal of Curriculum Studies, 33(I), 75-88. 